\title{
Physicochemical and functional properties of yoghurt made of cow milk, colostrum, and milk-colostrum combination
}

\author{
*Arkan, N.D., Setyawardani, T. and Rahardjo, A.H.D. \\ Faculty of Animal Science, Jenderal Soedirman University, Jl. Dr. Soeparno No. 60 Karangwangkal, \\ Purwokerto - Indonesia
}

\begin{abstract}
Article history:
Received: 19 February 2021

Received in revised form: 30

March 2021

Accepted: 17 June 2021

Available Online: 9 February

2022
\end{abstract}

\section{Keywords:}

Antioxidant,

Colour,

Colostrum,

Lactic acid,

Total solids

\section{DOI:}

https://doi.org/10.26656/fr.2017.6(1).120

\begin{abstract}
Yoghurt made from milk, colostrum and their combination are one of the innovations in product development. Colostrum is rich in nutrients that can be used as a functional food ingredient. This study aimed to analyze the physicochemical properties (colour, total solids, and fatty acids) and functional properties (antioxidant activity and fatty acid profile) of yoghurt made of additional colostrum. Colostrum is rich in nutrients for functional food ingredients. A total of six treatments of yoghurt made with milk-colostrum mixture $(100: 0 \%, 80: 20 \%, 60: 40 \%, 40: 60 \%, 20: 80 \%$ and 0:100\%) added. Each treatment was repeated four times, and data obtained were analyzed with the Analysis of Variance, followed by the Duncan test using SPSS ver 25 programs. Colostrum incorporated into yoghurt making could increase the yellow colour and the percentage of lactic acid. The research conclusion is the use of colostrum in making yoghurt can increase the yellow colour and the percentage of lactic acid. The highest antioxidant activity was observed in the production of yoghurt from the milk-colostrum mixture (20:80\%). Yoghurt made of $100 \%$ colostrum could increase oleic acid but decrease palmitic acid and myristic acid.
\end{abstract}

\section{Introduction}

The development of functional food in Indonesia has encouraged the innovation of milk-based functional beverage products. Consumers selection for food is not only based on taste but also health benefits. The development of fermented milk products in Indonesia in the last decade has been dominated by functional foodbased products, including yoghurt.

In general, yoghurt is produced from the fermentation of Streptococcus thermophilus and Lactobacillus bulgaricus, but probiotic lactic acid bacteria (LAB), like Lactobacillus acidophilus, have become popular to yoghurt. The roles of probiotics include maintaining the balanced intestinal microflora and nourishing the digestive tract. However, the raw material remains the determining factor to the physicochemical and functional quality of yoghurt.

Yoghurt raw materials can come from various types of milk, one of which is cow colostrum used in the present study. Colostrum has different properties compared to milk, including the yellow colour, thick consistency, and higher levels of protein, lactose, and fat (Setyawardani et al., 2020). Besides the source of nutrients like protein, carbohydrates, fats, vitamins and *Corresponding author.

Email:naofaldhia@gmail.com minerals, colostrum contains immune substances (Abdillah and Surjowardojo, 2018).

In Indonesia, colostrum is rarely utilized in the food sector and the excess production of colostrum is only steamed and added as a complement to snacks. Therefore, using colostrum as the raw material for yoghurt is worth investigating. It is expected that yoghurt made of combined raw materials including colostrum would produce distinctive properties, especially colour, thickness, fatty acid composition and antioxidant potential.

The colostrum used in this study is milked on the second and third days of postpartum. The colostrum has a non-rancid aroma, medium-thick texture, yellow colour and a higher quantity compared to that of first-day postpartum. Previous studies have used colostrum as the raw material for kefir (Setyawardani et al., 2020) and cheese (Astuti et al., 2021). Therefore, this research aimed to investigate the physicochemical and functional properties of yoghurt made with milk, colostrum, and their combinations.

\section{Materials and methods}

The study used $12 \mathrm{~L}$ of cow milk from Experimental eISSN: 2550-2166 / C 2022 The Authors. Published by Rynnye Lyan Resources 
Farm, Faculty of Animal Husbandry, Jenderal Soedirman University, commercial starter of probiotic yoghurt, 12L of colostrum from 2-3 days of milking mixture from BBPTU-HPT Baturraden, skim milk, aquades, $0.2 \mathrm{mM}$ DPPH solution (2,2-diphenyl-lpicrylhydrazyl), methanol solution, $0.1 \mathrm{~N} \mathrm{NaOH}$ solution, and $1 \%$ phenolphthalein (pp) indicator.

\subsection{Determination of physicochemical properties}

\subsubsection{Yoghurt making}

Yoghurt making began with the preparation of fresh milk and colostrum. The milk was pasteurized at $72^{\circ} \mathrm{C} / 15$ s. After the heat was reduced to $40^{\circ} \mathrm{C}$, the thawed colostrum and $10 \%$ yoghurt liquid starter were incorporated. The solution was incubated for $5 \mathrm{hrs}$ at $37-$ $45^{\circ} \mathrm{C}$, then the colour, total solids, lactic acid, antioxidants, and fatty acids were measured. Each treatment was repeated 4 times.

\subsubsection{Colour measurement}

The colour was measured using a colourimetry tool according to Widagdha and Nisa (2015). A total of 25 $\mathrm{mL}$ yoghurt sample was placed in an Erlenmeyer, the colourimetry was affixed to the surface of the sample, the reading button was set to $\mathrm{L}^{*}$ (brightness), $\mathrm{a}^{*}$ (redness), $b^{*}$ (yellowness), and the target button was pushed to record the reading.

\subsubsection{Total solids measurement}

The total solids were measured by the method according to AOAC International (1995). The porcelain cup was heated at $105^{\circ} \mathrm{C}$ for $1 \mathrm{hr}$, then the porcelain plate was put in a desiccator for 30 mins and then weighed (a). The empty cup was added with $5 \mathrm{~g}$ of colostrum yoghurt sample, weighed (b), and put in an oven at $105^{\circ} \mathrm{C}$ for 12 20 hrs.

\subsubsection{Lactic acid measurement}

Lactic acid was measured by the method according to SNI 2981:2009 (National Standardization Agency of Indonesia - BSN, 2009). A total of $20 \mathrm{~mL}$ of sample (W) was put into an Erlenmeyer, dissolved in $\mathrm{CO}_{2}$-free water 2 times the volume, and added with $2 \mathrm{~mL}$ of $1 \% \mathrm{pp}$ indicator and titrated with $0.1 \mathrm{~N} \mathrm{NaOH}$ solution until a constant pink colour was formed.

\subsection{Determination of functional properties}

\subsubsection{Antioxidant activity measurement}

The antioxidant activity was measured by the 2,2diphenyl-2-picryl-hydrazyl (DPPH) method (Awah, 2010). As much as $0.0019 \mathrm{~g}$ DPPH was put into a 100$\mathrm{mL}$ flask and shaken slowly. From the solution, $0.01 \mathrm{~g}$ was weighed on an analytical scale then dissolved with methanol into a $10-\mathrm{mL}$ flask for dissolution of 250,150 , 100,50 , and $25 \%$. The solvent was redissolved with methanol into a $10-\mathrm{mL}$ flask limit and the test tube was wrapped in aluminium foil. In the next step, the foil was inserted into the sample ( $1 \mathrm{~mL}$ sample $+4 \mathrm{~mL}$ DPPH $)$, stand for 30 mins, then used to prepare for the blank (5 $\mathrm{mL}$ methanol) and control $(1 \mathrm{~mL}$ methanol $+4 \mathrm{~mL}$ DPPH) samples. The solvent was measured using a spectrophotometer with an absorbance of $517 \mathrm{~nm}$ and the results have recorded the results. The absorption value of the DPPH solution is calculated as per cent inhibition $(\%)$.

\subsubsection{Fatty acid profile measurement}

The fatty acid profile was measured by the method according to Golay and Dong (2012). Addition of internal standard solutions to samples, manufacture of fatty acid methyl esters (FAMEs) by direct transesterification with methanol sodium methoxide for liquid samples; dissolving in water and direct transesterification with methanol sodium methoxide for powder samples. The FAME separation uses capillary gas-liquid chromatography. Identification by comparing with pure standard retention times and quantification as fatty acids with reference to internal standards. Transesterification performance verification using the second internal standard.

\subsection{Statistical analysis}

The data obtained were analyzed with the Analysis of Variance, followed by the Duncan test using SPSS ver 25 programs.

\section{Results and discussion}

\subsection{Determination of physicochemical properties}

The results of the analysis of yoghurt using colostrum in terms of the physicochemical properties of colour, total solids and lactic acid are in Table 1.

\subsubsection{Yoghurt colour}

Colour indicator of a product is crucial because it is the first visual clue for consumers when selecting a product before purchase (Burton et al., 2014). The raw materials did not affect the brightness $\left(\mathrm{L}^{*}\right)$ and redness $\left(a^{*}\right)$ of yoghurt but affected the yellowness $\left(b^{*}\right)$ (Table 1). The fermentation process can turn the colour of a product cloudy, but the changes are not evident, especially using a sensory test (Lestari et al., 2018). The white colour is generated by casein with the absence of carotene, while the slight yellowness in colour is generated by the fat granules in milk (Khoiriyah and Fatchiyah, 2013). 
Table 1. Physicochemical properties of yoghurt made with milk-colostrum mixes

\begin{tabular}{|c|c|c|c|c|c|c|c|}
\hline \multirow{2}{*}{ Properties } & \multicolumn{6}{|c|}{ Proportion of colostrum in the mixes $(\%)$} & \multirow{2}{*}{ Sig. } \\
\hline & 0 & 20 & 40 & 60 & 80 & 100 & \\
\hline \multicolumn{8}{|l|}{ Colour } \\
\hline $\mathrm{L}^{*}$ & $56.82 \pm 6.98$ & $60.85 \pm 6.45$ & $58.41 \pm 4.51$ & $58.57 \pm 7.78$ & $57.92 \pm 10.13$ & $57.73 \pm 6.45$ & ns \\
\hline$a^{*}$ & $-6.84 \pm 0.39$ & $-6.71 \pm 0.26$ & $-6.30 \pm 0.31$ & $-5.33 \pm 0.95$ & $-4.91 \pm 1.24$ & $-5.24 \pm 0.82$ & ns \\
\hline$b^{*}$ & $8.77 \pm 0.93^{\mathrm{a}}$ & $11.19 \pm 0.46^{\mathrm{ab}}$ & $16.31 \pm 7.64^{\mathrm{b}}$ & $15.96 \pm 0.84^{\mathrm{bc}}$ & $17.55 \pm 2.44^{\mathrm{c}}$ & $17.36 \pm 4.08^{\mathrm{c}}$ & $*$ \\
\hline Total solids $(\%)$ & $17.10 \pm 5.74$ & $17.23 \pm 6.57$ & $13.49 \pm 5.56$ & $12.68 \pm 7.65$ & $11.23 \pm 10.45$ & $11.79 \pm 8.18$ & ns \\
\hline Lactic acid $(\%)$ & $1.08 \pm 0.12^{\mathrm{a}}$ & $1.13 \pm 0.16^{\mathrm{a}}$ & $1.31 \pm 0.16^{\mathrm{ab}}$ & $1.54 \pm 0.34^{\mathrm{abc}}$ & $1.71 \pm 0.37^{\mathrm{bc}}$ & $1.85 \pm 0.41^{\mathrm{c}}$ & $* *$ \\
\hline
\end{tabular}

Values are presented as mean $\pm \mathrm{SD}$. Values with different superscripts within the same row are significantly different $(\mathrm{P}<0.05)$. $\mathrm{L}^{*}$ : brightness value, $\mathrm{a}^{*}$ : brightness value, $\mathrm{b}^{*}$ : yellowness value. *: significant, **: very significant, ns: non-significant $(\mathrm{P}>0.05)$.

A milk-colostrum mixture $(20: 80 \%)$ can increase the yellow colour of yoghurt by 9.41 . The yellow colour is the result of beta carotene in milk which, according to Widagdha and Nisa (2015), seems linear to the increased viscosity of yoghurt. Colostrum colour is associated with $65 \% \beta$-carotene content (Setyawardani et al., 2020). Meanwhile, the reddish-yellow colostrum is mainly due to carotenoids. Carotenoid levels are high in the earlymilked fat-enriched colostrum but decrease rapidly when the milk secretions turn into normal milk (McGrath et al., 2016). Carotenoids are natural pigments derived from plants in the form of vitamin precursors found in milk fat and give a yellow colour (Krisnaningsih and Efendi, 2015). The value of $b^{*}$ shows the level of yellowness on a scale of -100 to +100 , in which negative values indicate a yellowness tendency, while positive values are a bluish colour (Pomeranz, 2013).

\subsubsection{Total solids of yoghurt}

Yoghurt made of different combinations of raw materials (milk, colostrum, or both) did not contain different total solids. Table 1 shows that total solids tend to increase in yoghurt made of milk added with colostrum. The range of total solids in this study is within the range of SNI 2981:2009 standard, namely a minimum of $8.2 \%$ (National Standardization Agency of Indonesia-BSN, 2009).

The fermentation process of LAB would produce metabolites in the form of lactic acid. According to Fardiaz (2003), metabolites would be secreted from the cell and accumulate in the fermentation fluid, so the residue of total sugar, lactic acid, and organic acids are counted as the total dissolved solids. The total solids content in milk can affect the total solids of the yoghurt. A previous study reported $12-14 \%$ of total solids is sufficient to obtain a sound consistency of yoghurt (Djali et al., 2018).

The total solid component consists of total sugar, pigments, organic acids, and proteins (Ismawati et al., 2016). The total solids of yoghurt are influenced by the concentration of the starter; therefore, the increased LAB would hydrolyze the total solids of milk, such as protein.
The protein is degraded into amino acids while oligosaccharides and lactose are converted into lactic acid, therefore, reducing the total solids of the product (Purba et al., 2012).

\subsubsection{Lactic acid of yoghurt}

Yoghurt made of $100 \%$ colostrum has the highest percentage of lactic acid (1.85\%). The statistical analysis showed that colostrum significantly $(\mathrm{P}<0.05)$ affected lactic acid levels in the yoghurt product. The range of lactic acid in this study is within the range of SNI 2981:2009 standard, namely $0.5-2.0 \%$ (National Standardization Agency of Indonesia - BSN, 2009). Additionally, yoghurt made of $100 \%$ colostrum could increase lactic acids by $0.77 \%$.

Lactic acid produced by (LAB) would be secreted from the cells and accumulated in the substrate, thereby increasing acidity. The increased lactic acid is due to the activity of LAB that degrades lactose and other sugars into lactic acid (Legowo et al., 2009). According to Kumalasari et al. (2013), the fermentation process in making yoghurt can break down lactose (milk sugar) into lactic acid and various components, such as aroma and flavour. Lactose levels continue to decline because they are used by the cells to grow and to form lactic acid. The more lactose is utilized, the higher the lactic acid (Utami et al., 2010). The presence of acid in milk is mainly caused by the activity of acid-forming bacteria. These bacteria can convert lactose into lactic acid which eventually reduces milk pH (Afriani, 2010).

In making yoghurt, the $\mathrm{pH}$ decreases by fermentation of LAB which converts lactose into lactic acid (Artini et al., 2015). During fermentation, the proteolysis of milk protein produces peptides and amino acids which contribute to the formation of flavour compounds (Sert et al., 2017). LAB play a role in forming the texture of yoghurt and other fermented milk products (Yang et al., 2014). 


\subsection{Determination of functional properties}

\subsubsection{Antioxidant activity of yoghurt}

The parameter to interpret the test results is the $\mathrm{IC}_{50}$ value, which is defined as the concentration of antioxidant compounds that causes a $50 \%$ loss of DPPH activity. Table 2 shows that all test samples of each treatment had an $\mathrm{IC}_{50}$ value under 50 . Figure 1 shows the line equations of yoghurt antioxidant activity. Therefore, yoghurt made with colostrum substitution has a very strong antioxidant value $\left(\mathrm{IC}_{50}\right.$ value $\left.<50\right)$. On the other hand, yoghurt made with combined milk and colostrum $(20: 80 \%)$ showed the highest antioxidant activity and the $\mathrm{IC}_{50}$ dropped from 47.52 to 16.35 . It shows that yoghurt made of combined milk-colostrum $(20: 80 \%)$ can increase the antioxidant activity of yoghurt. It confirms Badarinath (2011) that $\mathrm{IC}_{50}<50$ would produce a very strong antioxidant, instead of strong (50-100), moderate (100-150), or weak (151-200). According to Koleangan et al. (2014), the lower the $\mathrm{IC}_{50}$ value, the higher the antioxidant activity.

Food processing and fermentation can increase antioxidant activity where isoflavone compounds are hydrolyzed into free compounds or aglycones with higher activity (Wulandari and Pramono, 2014). Antioxidant compounds could delay and prevent the process of lipid oxidation. Also, a longer fermentation time can increase the antioxidant activity of yoghurt. (Kartikasari and Nisa, 2014). Antioxidants can act as a contributor to hydrogen radicals or the free radical acceptors to delay the initiation stage of free radical formation (Dungir et al., 2012).

Antioxidant activity is one of the fundamental biological activities for life. Antioxidant intake is necessary to avoid oxidative stress and its implications to several diseases, including neurodegenerative disorders, hypertension, cancer, and inflammatory diseases (Oussaief et al., 2019). Even a low level of antioxidants

Table 2. Antioxidant activity of yoghurt made with milk-colostrum mixes

\begin{tabular}{cccc}
\hline Treatments & Line equations & Y value & $\mathrm{X}$ or $\mathrm{IC}_{50}$ value \\
\hline Milk $(100 \%)$ & $\mathrm{Y}=0.0553 \mathrm{x}+47.372$ & 50 & 47.52 \\
Milk-colostrum mix $(80: 20 \%)$ & $\mathrm{Y}=0.0388 \mathrm{x}+48.452$ & 50 & 39.89 \\
Milk-colostrum mix $(60: 40 \%)$ & $\mathrm{Y}=0.0461 \mathrm{x}+48.304$ & 50 & 36.78 \\
Milk-colostrum mix (40:60\%) & $\mathrm{Y}=0.0328 \mathrm{x}+48.834$ & 50 & 35.54 \\
Milk-colostrum mix (20:80\%) & $\mathrm{Y}=0.0373 \mathrm{x}+49.390$ & 50 & 16.35 \\
Colostrum (100\%) & $\mathrm{Y}=0.0386 \mathrm{x}+49.258$ & 50 & 19.22 \\
\hline
\end{tabular}
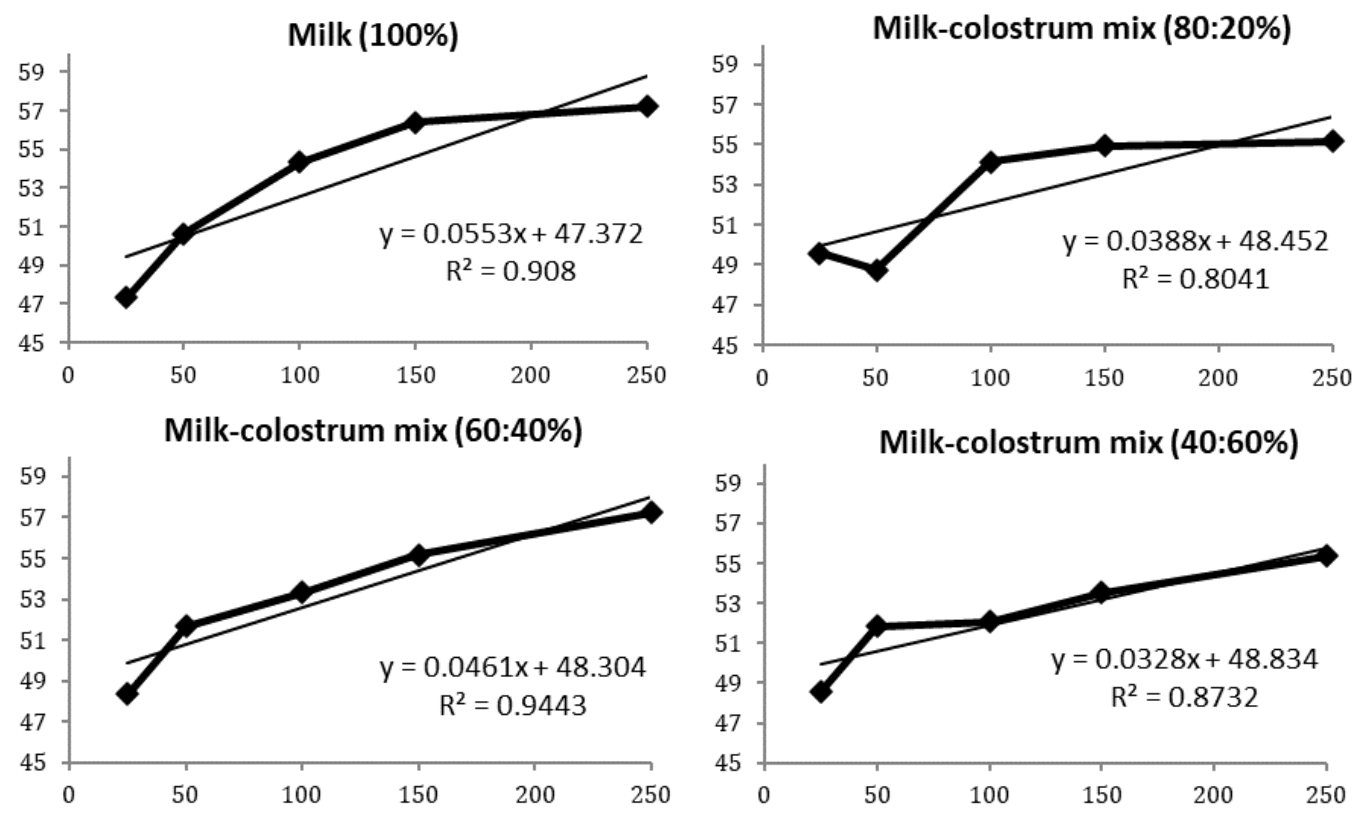

Milk-colostrum mix (20:80\%)
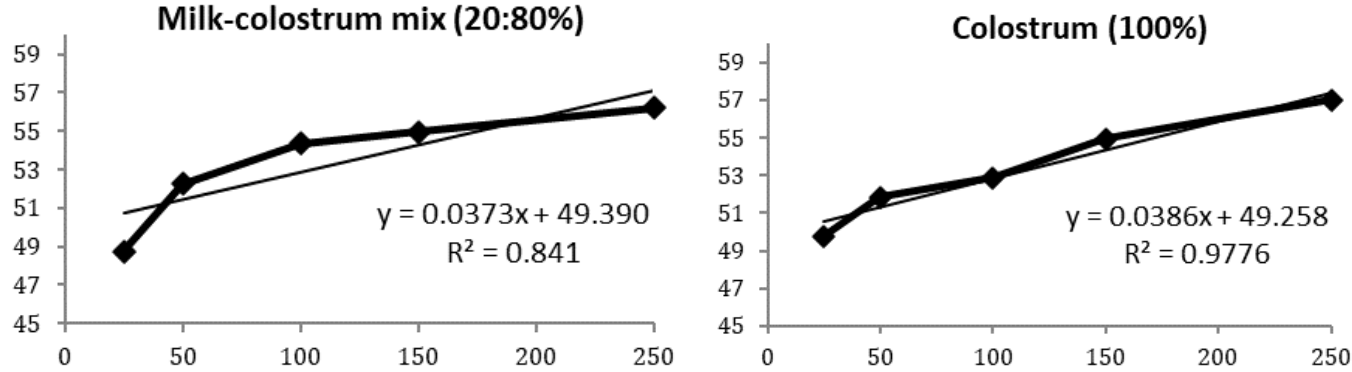

Figure 1. Equation of yoghurt antioxidant activity lines 
Table 3. Fatty acid profile of yoghurt made with milk-colostrum mixes

\begin{tabular}{|c|c|c|c|c|c|c|}
\hline \multirow{2}{*}{ Components } & \multicolumn{6}{|c|}{ Proportion of colostrum in the mixes $(\%)$} \\
\hline & 0 & 20 & 40 & 60 & 80 & 100 \\
\hline Fat Content & 1.20 & 0.94 & 1.49 & 0.88 & 1.10 & 1.46 \\
\hline \multicolumn{7}{|l|}{ Fatty Acid } \\
\hline Butryc Acid, C4:0 & 0.76 & 0.88 & 0.85 & 1.09 & 1.00 & 1.14 \\
\hline Caproic Acid, C6:0 & 0.78 & 0.81 & 0.78 & 0.96 & 0.87 & 0.82 \\
\hline Caprilic Acid, C8:8 & 0.74 & 0.67 & 0.94 & 0.87 & 0.79 & 0.58 \\
\hline Capric Acid, C10:0 & 1.57 & 1.48 & 1.69 & 1.62 & 1.47 & 1.09 \\
\hline Undecanoic Acid, C11:0 & 0.16 & 0.14 & 0.12 & 0.12 & 0.11 & 0.08 \\
\hline Lauric Acid, C12:0 & 3.55 & 2.82 & 5.83 & 3.85 & 3.51 & 1.93 \\
\hline Tridecanoic Acid C13:0 & 0.05 & 0.05 & 0.07 & 0.07 & 0.06 & 0.05 \\
\hline Myristic Acid, C14:0 & 6.69 & 6.94 & 8.18 & 8.37 & 7.61 & 5.80 \\
\hline Myristoleic Acid, C14:1 & 0.56 & 0.51 & 0.42 & 0.60 & 0.38 & 0.22 \\
\hline Pentadecanoic Acid, C15:0 & 0.64 & 0.68 & 0.61 & 0.97 & 0.57 & 0.59 \\
\hline Palmitic Acid, C16:0 & 18.35 & 20.06 & 22.93 & 24.65 & 22.28 & 19.05 \\
\hline Palmitoleic Acid, C16:1 & 1.20 & 1.19 & 1.17 & 1.27 & 1.15 & 0.83 \\
\hline Heptadecanoic Acid, C17:0 & 0.28 & 0.34 & 0.35 & 0.36 & 0.33 & 0.35 \\
\hline Cis-10-Heptadecanoic Acid, C17:1 & 0.13 & 0.15 & 0.16 & 0.18 & 0.17 & 0.17 \\
\hline Stearic Acid, C18:0 & 10.84 & 12.42 & 12.07 & 10.71 & 9.75 & 13.92 \\
\hline Elaidic Acid, C18:1n9t & 3.12 & 3.23 & 2.81 & 2.66 & 2.42 & 2.74 \\
\hline Oleic Acid, C18:1n9c & 19.20 & 21.22 & 20.84 & 20.96 & 19.07 & 21.49 \\
\hline Linoleic Acid, C18:2n6c & 1.77 & 1.81 & 2.00 & 2.04 & 1.85 & 1.50 \\
\hline Arachidic Acid, C20:0 & 0.14 & 0.16 & 0.17 & 0.16 & 0.15 & 0.18 \\
\hline$\gamma$-Linolenic Acid, C18:3n6 & 0.02 & 0.03 & 0.03 & 0.04 & 0.03 & 0.00 \\
\hline Cis-11-Eicosenoic Acid, C20:1 & 0.27 & 0.25 & 0.30 & 0.35 & 0.32 & 0.18 \\
\hline Linoleic Acid, C18:3n3 & 0.52 & 0.50 & 0.44 & 0.40 & 0.36 & 0.36 \\
\hline Heneicosanoic Acid, C21:0 & 0.05 & 0.05 & 0.05 & 0.04 & 0.04 & 0.05 \\
\hline Cis-11, 14-Eicosedinoic Acid, C20:2 & 0.04 & 0.04 & 0.05 & 0.05 & 0.05 & 0.04 \\
\hline Behenic Acid, C22:0 & 0.08 & 0.06 & 0.08 & 0.07 & 0.06 & 0.10 \\
\hline Cis-8, 11, 14-Eicosetrinoic Acid, C20:3n6 & 0.06 & 0.07 & 0.14 & 0.21 & 0.20 & 0.08 \\
\hline Arachidonic Acid, C20:4n6 & 0.06 & 0.12 & 0.18 & 0.28 & 0.25 & 0.22 \\
\hline Tricosanoic Acid, C23:0 & 0.05 & 0.04 & 0.05 & 0.04 & 0.04 & 0.06 \\
\hline Cis-5, 8, 11, 14, 17-Eicosapentaenoic Acid, C20:5n3 & 0.00 & 0.05 & 0.10 & 0.14 & 0.13 & 0.09 \\
\hline Cis-4,7,10,13,16,19-Docosahexaenoic Acid, C22:6n3 & 0.00 & 0.00 & 0.00 & 0.00 & 0.00 & 0.03 \\
\hline Total & 71.68 & 76.75 & 83.40 & 83.13 & 75.01 & 73.70 \\
\hline
\end{tabular}

could prevent oxidative damage to various biomolecules associated with various diseases including cancer, liver disease, ageing, arthritis, inflammation, diabetes (Srivastava et al., 2015). Therefore, yoghurt with a high antioxidant activity can reduce oxidative stress and prevent the accompanying implications. In addition, probiotic bacteria in yoghurt, such as Lactobacillus acidophilus and Bifidobacterium lactis can increase the antioxidant status in people with type 2 Diabetes Mellitus. As a result, it prevents disease complications and inhibits the early stages of retinopathy, nephropathy, and neuropathy. Also, antioxidants can inhibit microvascular complications, reduce the incidence of coronary heart disease and improve the cardiac autonomic nervous system (Rosiana and Khoiriyah, 2018).

\subsubsection{Fatty acid profile of yoghurt}

The present study produced $53.12 \%$ unsaturated fatty acids and $46.88 \%$ saturated fatty acids. Table 3 shows that yogurt made of $100 \%$ colostrum produced the highest unsaturated/oleic acid (C18:1n9) of $21.49 \%$, while a mixture of milk-colostrum $(40: 60 \%)$ yogurt produced the highest saturated/palmitic acid (C16:0) by $24.65 \%$. Butyric, capric, myristic, palmitic, stearic, and oleic acids are the dominant free fatty acids in yoghurt (Senel et al., 2011). Similarly, Ilyasoglu et al. (2014) stated that oleic acid is the most abundant fatty acid detected in the product, followed by linoleic, palmitic and stearic acids. Palmitic acid is a saturated fatty acid that can be found in meat and dairy products (50-60\%), cocoa butter $(26 \%)$, and olive oil $(8-20 \%)$. Despite the presumed adverse effects on chronic disease in adults, palmitic acid is an important component of cell membranes and for lipid secretion and transport (Aisyah et al., 2019).

Fermentation is a tool to increase the nutritional value of food and beverages, both the bioavailability of bioactive compounds (i.e., polyphenols) and the production of healthy final products. Short-chained fatty acids (SCFA) is small organic monocarboxylic acids 
with different chain lengths (two to six carbon atoms) and beneficial effects on human health. These fatty acids are generally produced by the intestinal microbiota as the final product of fermentation of food polysaccharides, including fibre and resistant starch. The most representative SCFAs are acetic acid (C2), propionic acid (C3) and butyric acid (C4) produced in a molar rate of about 60:20:20 (Annunziata et al., 2020).

This study observed that the fermentation process to make yoghurt from 100\% colostrum has decreased the amount of saturated fatty acids (SFA), including palmitic acid (C16:0) from $22.28 \%$ to $19.5 \%$, myristic acid (C14:0) from $8.37 \%$ to $5.80 \%$, as well as increased unsaturated fatty acids, namely oleic acid (C18:1n9c) by $2,42 \%$. The highest saturated fatty acids (SFA) are palmitic acid (C16:0), followed by short-chained saturated fatty acids (C4-C10), medium-chained saturated fatty acids (C11-C15), long-chained saturated fatty acids (C15-C24), unsaturated fatty acids monounsaturated fatty acids (MUFA), and polyunsaturated fatty acids (PUFA), namely 10\%, $16.67 \%, 23.33 \%, 20 \%$, and $30 \%$, respectively. The higher the colostrum, the higher the palmitic acid (C16:0) but the lower the myristic acid (C14:0). PUFAs help lower cholesterol and reduce the risk of coronary disease due to an increase in high-density lipoprotein (HDL) in the blood (Boycheva et al., 2012).

Fatty acids found in nature are monocarboxylic acids with mono chains and an even number of carbon atoms consisting of two groups: saturated fatty acids and unsaturated fatty acids. Unsaturated fatty acids can reduce cholesterol levels in the blood (Purnama et al., 2011), while saturated fatty acids increase blood cholesterol. The longer the carbon chain, the greater the tendency to increase cholesterol levels. In addition, saturated fatty acids do not have double bonds, while unsaturated fatty acids do not (Amahorseja, 2018). Therefore, polyunsaturated fatty acids can reduce the risk of metabolic syndrome by increasing HDL cholesterol levels and reducing total cholesterol levels or cholesterol deposits in blood vessels, thus preventing atherosclerosis and coronary heart disease. Also, polyunsaturated fatty acids increase the elasticity of blood vessels thereby reducing the risk of hypertension (Wiardani et al., 2011).

\section{Conclusion}

The use of colostrum in making yoghurt can increase the yellow colour and the percentage of lactic acid. The highest antioxidant activity was observed in the production of yoghurt from the milk-colostrum mixture (20:80\%). Yoghurt made of $100 \%$ colostrum could increase oleic acid but decrease palmitic acid and myristic acid.

\section{References}

Abdillah, Z. and Surjowardojo, P. (2018). Hubungan BCS dengan Kualitas Kolostrum Ditinjau dari Solid Non Fat dan Berat Jenis Kolostrum Sapi FH. Journal of Tropical Animal Production, 19(1), 53-29. https:// doi.org/10.21776/ub.jtapro.2018.019.01.8

Afriani. (2010). Pengaruh Penggunaan Starter Bakteri Asam Laktat Lactobacillus plantarum dan Lactobacillus fermentum terhadap Total Bakteri Asam Laktat, Kadar Asam dan Nilai pH Dadih Susu Sapi. Jurnal Ilmiah Ilmu-Ilmu Peternakan, 8(6), 279285. https://doi.org/10.22437/jiiip.v0i0.114 [In Bahasa Indonesia].

Aisyah, N.F., Aisyah, N., Kusuma, T.S. and Widyanto, R.M. (2019). Profil Asam Lemak Jenuh dan Tak Jenuh serta Kandungan Kolesterol Nugget Daging Kelinci New Zealand White (Oryctolagus cuniculus). Jurnal Al-Azhar Indonesia Seri Sains dan Teknologi, 5(2), 92-100. https://doi.org/10.36722/ sst.v5i2.356 [In Bahasa Indonesia].

Amahorseja, A.L. (2018). Profil Asam Lemak Ikan Tuna (Thunnus, sp.) Asap. Jurnal HIBUALAMO, 2(1), $47-$ 57. [In Bahasa Indonesia].

Annunziata, G., Arnone, A., Ciampaglia, R., Tenore, G.C. and Nobellino, E. (2020). Fermentation of Foods and Beverages as a Tool for Increasing Availability of Bioactive Compounds. Focus on Short-Chain Fatty Acids. Foods, 9(8), 999. https:// doi.org/10.3390/foods9080999

AOAC International. (1995). Official Methods of Analysis Chemist. Vol. 1A. Washington DC, USA: AOAC.

Artini, N.P.R., Manuaba, I.B.P. and Wirajana, I.N. (2015). Variasi Konsentrasi Buah Asam (Tamarindus indica L.) dan Susu Skim Terhadap Kualitas Yogurt Kunir Asam. Journal of Applied Chemistry, 3(2), 63-74. [In Bahasa Indonesia].

Astuti, F.D., Setyawardani, T. and Santosa, S.S. (2021). The physical characteristics of cheese made of milk, colostrum and both during the ripening. Journal of the Indonesian Tropical Animal Agriculture, 46(1), 75-83. https://doi.org/10.14710/jitaa.46.1.75-83 [In Bahasa Indonesia].

Awah, F.M., Uzoegwu, P.N., Oyugi, J.O., Rutherford, J., Ifeonu, P., Yao, X.J., Fawker, K.R. and Eze, M.O. (2010). Free Radical Scavenging Activity and Immunomodulatory Effect of Stratchyarpheta angustifolia leaf extract. Food Chemistry, 199(4), 1409-1416. https://doi.org/10.1016/ j.foodchem.2009.09.020

Badarinath, A. (2011). A Review on In-Vitro Antioxidant Methods: Comparisons, Correlations 
and Considerations. International Journal of PharmTech Research, 2, 1276-1285.

Boycheva, S., Mihaylova, G., Naydenova, N. and Dimitrov, T. (2012). Amino acid and fatty acid content of yogurt supplemented with walnut and hazelnut pieces. Trakia Journal of Sciences, 10(2), 17-25.

Burton, E., Arief, I.I. and Taufik, E. (2014). Formulasi Yoghurt Probiotik Karbonasi dan Potensi Sifat Fungsionalnya. Jurnal Ilmu Produksi dan Teknologi Hasil Peternakan, 2(1), 213-218. [In Bahasa Indonesia].

Djali, M., Huda, S. and Andriani, L. (2018). Karakteristik Fisikokimia Yogurt Tanpa Lemak dengan Penambahan Whey Protein Concentratedan Gum Xanthan. Agritech, 38(2), 178-186. https:// doi.org/10.22146/agritech.22451 [In Bahasa Indonesia].

Dungir, S.G., Katja, D.G. and Kamu, V.S. (2012). Aktivitas Antioksidan Ekstrak Fenolik dari Kulit Buah Manggis (Garcinia mangostana L.). Jurnal Mipa Unsrat Online, 1(1), 11-15. https:// doi.org/10.35799/jm.1.1.2012.424 [In Bahasa Indonesia].

Fardiaz, S. (2003). Mikrobiologi Pangan Lanjut. Bogor, Indonesia: Pusat Antar Universitas Pangan dan Gizi IPB.

Golay, P.A. and Dong, Y. (2012). Determination of Labeled Fatty Acids Content in Milk Products and Infant Formula Capillary Gas Chromatography: Single Laboratory Validation, First Action 2012.13. Journal of AOAC International, 98(6), 1679-1696. https://doi.org/10.5740/jaoacint.15-0140

Ismawati, N., Nurwantoro, N. and Pramono, Y.B. (2017). Nilai pH, Total Padatan Terlarut, dan Sifat Sensoris Yoghurt dengan Penambahan Ekstrak Bit (Beta Vulgaris L.). Jurnal Aplikasi Teknologi Pangan, 5(3), 89-93. http://dx.doi.org/10.17728/ jatp.181 [In Bahasa Indonesia].

Ilyasoglu, H., Yilmaz, F., Burnaz, N.A. and Baltaci, C. (2014). Preliminary assessment of a yoghurt-like product manufactured from hazelnut slurry: Study using response surface methodology. Food Science and Technology, 30(1), 1-9. https://doi.org/10.1016/ j.lwt.2014.06.023

Kartikasari, D.I. and Nisa, F.C. (2014). Pengaruh Penambahan Sari Buah Sirsak dan Lama Fermentasi terhadap Karakteristik Fisik dan Kimia Yoghurt. Jurnal Pangan dan Agroindustri, 2(4), 239-248. [In Bahasa Indonesia].

Khoiriyah, L.K. and Fatchiyah. (2013). Karakter Biokimia dan Profil Protein Yogurt Kambing PE
Difermentasi Bakteri Asam Laktat (BAL). Journal Expperimental Life Science, 3(1), 1-6. https:// doi.org/10.21776/ub.jels.2013.003.01.01 [In Bahasa Indonesia].

Koleangan, H.S., Runtuwene, M.R. and Kamu, V.S. (2014). Penentuan Aktivitas Antioksidan Berdasarkan Nilai IC50 Ekstrak Metanol dan Fraksi Hasil Partisinya pada Kulit Biji Pinang Yaki (Areca vestiaria Giseke). Jurnal MIPA, 3, 149-154. https:// doi.org/10.35799/jm.3.2.2014.6002 [In Bahasa Indonesia].

Krisnaningsih, A. and Efendi, A. (2015). Pengaruh Penggunaan Level Susu Skim dann Masa Inkubasi pada Suhu Ruang terhadap pH dan Organoleptik Stirred Yogurt. Jurnal Alam Hijau, 6(2), 54-63. [In Bahasa Indonesia].

Kumalasari, K.E.D., Legowo, A.M. and Al-Baarri, A.N. (2013). Total Bakteri Asam Laktat, Kadar Laktosa, $\mathrm{pH}$, Keasaman, Kesukaan Drink Yogurt dengan Penambahan Ekstrak Buah Kelengkeng. Jurnal Aplikasi Teknologi Pangan, 2(4), 165-168. [In Bahasa Indonesia].

Legowo, A. and Kusrahayu, M.S. (2009). Ilmu dan Teknologi Susu. Semarang, Indonesia: Badan Penerbit Universitas Diponegoro. [In Bahasa Indonesia].

Lestari, M.W., Bintoro, V.P. and Rizqiati, H. (2018). Pengaruh Lama Fermentasi terhadap Tingkat Keasaman, Viskositas, Kadar Alkohol, dan Mutu Hedonik Kefir Air Kelapa. Jurnal Teknologi Pangan, 2(1), 8-13. https://doi.org/10.14710/ jtp.2.1.\%25p [In Bahasa Indonesia].

McGrath, B.A., Fox, P.F., McSweeney, P.L.H. and Kelly, A.L. (2016). Composition and properties of bovine colostrum: a review. Dairy Science and Technology, 96(2), 133-158. https://doi.org/10.1007/ s13594-015-0258-x

National Standardization Agency of Indonesia - BSN (2009). Yogurt (SNI 2981:2009). Jakarta, Indonesia: Badan Standardisasi Nasional Indonesia. [In Bahasa Indonesia].

Oussaief, A., Jrad, Z., Adt, I., Dbara, M., Khorchani, T. and El-Hatmi, H. (2019). Antioxidant activities of enzymatic-hydrolysed proteins of dromedary (Camelus dromedarius) colostrum. International Journal of Dairy Technology, 73(2), 12668. https:// doi.org/10.1111/1471-0307.12668

Pomeranz, Y. (2013). Food Analysis: Theory and Practice. Boston, USA: Springer Science and Business Media.

Purba, R.A., Rusmarilin, H. and Nurminah, M. (2012). Studi Pembuatan Yoghurt Bengkuang Instan dengan 
Berbagai Konsentrasi Susu Bubuk dan Starter. Jurnal Rekayasa Pangan dan Pertanian, 1(1), 1-15. [In Bahasa Indonesia].

Purnama, A., Malaka, R. and Ako, A. (2011). Pengaruh Penambahan Minyak Ikan dan Minyak Biji Bunga Matahari dalam Yogurt Susu Skim Terhadap Level Kolesterol Hewan Coba Mencit (Mus musculus). Jurnal Ilmu Teknologi Peternakan, 1(3), 159-166. [In Bahasa Indonesia].

Rosiana, N.M. and Khoiriyah, T. (2018). Yogurt Tinggi Antioksidan dan Rendah Gula dari Sari Buah Apel Rome Beauty dan Madu. Jurnal Ilmu Teknologi Hasil Ternak, 13(2), 81-90. https://doi.org/10.21776/ ub.jitek.2018.013.02.2 [In Bahasa Indonesia].

Senel, E., Atamer, M., Gursoy, A. and Oztekin, F.S. (2011). Changes in some properties of strained (Süzme) goat's yoghurt during storage. Small Ruminant Research, 99(2-3), 171-177. https:// doi.org/10.1016/j.smallrumres.2011.03.042

Sert, D., Mercan, E. and Dertli, E. (2017). Characterisation of lactic acid bacteria from yogurtlike product fermented with pine cone and determination of their role on physicochemical, textural and microbiological properties of product. LWT, 78, 70-76. https://doi.org/10.1016/ j.lwt.2016.12.023

Setyawardani, T., Sumarmono, J. and Widayaka, K. (2020). Physical and Microstructural Characteristics of Kefir Made of Milk and Colostrum. Buletin Peternakan, 44(1), 43-49. https://doi.org/10.21059/ buletinpeternak.v44i1.49130

Setyawardani, T., Sumarmono, J., Arief, I.I., Rahardjo, A.H.D., Widayaka, K. and Santosa, S.S. (2020). Improving composition and microbiological characteristics of milk kefir using colostrum. Food Science and Technology, 40(2), 699-707. https:// doi.org/10.1590/fst.31719

Srivastava, P., Prasad, S.G.M., Ali, M.N. and Prasad, M. (2015). Analysis of antioxidant activity of herbal yoghurt prepared from different milk. The Pharma Innovation Journal, 4(3), 18-20.

Utami, R., Andriani, M.A.M. and Putri, Z.A. (2010). Kinetika Fermentasi Yoghurt yang Diperkaya Ubi Jalar (Ipomea batatas). Journal of Sustainable Agriculture, 25(1), 50-55. https://doi.org/10.20961/ carakatani.v25i1.15736 [In Bahasa Indonesia].

Wiardani, N.K., Sugani, P.P.S. and Gumala, N.M.Y. (2011). Konsumsi lemak total, lemak jenuh, dan kolesterol sebagai faktor risiko sindroma metabolik pada masyarakat perkotaan di Denpasar. Jurnal Gizi Klinik Indonesia, 7(3), 107-114. https:// doi.org/10.22146/ijcn.17751 [In Bahasa Indonesia].
Widagdha, S. and Nisa, F.C. (2015). Pengaruh Penambahan Sari Anggur (Vitis vinifera L.) dan Lama Fermentasi terhadap Karakteristik Fisiko Kimia Yoghurt. Jurnal Pangan dan Agroindustri, 3 (1), 248-258. [In Bahasa Indonesia].

Wulandari, W.A. and Pramono, A. (2014). Pengaruh Pemberian Yoghurt Koro Pedang (Canavalia ensiformis) terhadap Kadar Serum Trigliserida Tikus Sprague Dawley Hipertrigliseridemia. Journal of Nutrition College, 3(1), 172-178. https:// doi.org/10.14710/jnc.v3i1.4555 [In Bahasa Indonesia].

Yang, T., Wu, K., Wang, F., Liang, X., Liu, Q., Li, G. and Li, Q. (2014). Effect of exopolysaccharides from lactic acid bacteria on the texture and microstructure of buffalo yoghurt. International Dairy Journal, 34(2), 252-256. https://doi.org/10.1016/ j.idairyj.2013.08.007 